\title{
Tourist destination marketing: from sustainability myopia to memorable experiences
}

\author{
Dr Paul Hanna ${ }^{1 *}$; Prof Xavier Font ${ }^{1}$; Prof Caroline Scarles ${ }^{1}$; Dr Clare Weeden²; Miss Charlotte \\ Harrison $^{1}$ \\ 1 University of Surrey \\ 2 University of Brighton \\ *Corresponding author: p.hanna@surrey.ac.uk
}

\begin{abstract}
This study explores the way in which consumers interpret and process the marketing and communication of sustainable forms of tourism in destinations, in order to inform policy makers about the appropriateness of different types of sustainability messages. Through a thematic analysis of focus group data, we explore the ways in which consumers engage with, and respond to, explicit discourses of sustainability in marketing a tourist destination. We find that overt discourses of sustainability are often rejected by consumers, thus suggesting that messages concerned with sustainability should place greater priority upon consumer experience and opportunities afforded by the purchase and consumption of the travel experience (that happens to be sustainable) they can expect at their chosen destination. As such, commitments to sustainability manifest within organisational philosophy and practice should not drive the principle, overt discourse communicated to consumers. Rather, as embedded within product and practice, such messages would have greater power and effect if they occupied a more subliminal position in destination marketing materials.
\end{abstract}

Keywords: Sustainability; Messaging; Marketing; Discourse; Consumer experience

\section{Highlights:}

- Widens the scope of destination marketing research by focusing on discourses of sustainability;

- Reveals the ways in which individuals understand and respond to explicit and implicit sustainability messaging;

- Illustrates how discourses of sustainability are often rejected by consumers;

- Finds that messages concerned with sustainability should place greater priority upon a consumer experience;

- Discusses the ways that sustainability marketing has greater power and effect if more subliminal.

To cite this article:

Hanna, P., Font, X., Scarles, C., Weeden, C., Harrison, C. (In print) Tourist destination marketing: from sustainability myopia to memorable experiences. Journal of Destination Marketing \& Management. 


\section{Introduction}

There has been increased public awareness of the consequences of excessive consumerism and the need to use marketing as one of a suite of techniques to promote sustainable behaviour change (Belz \& Peattie, 2012; Font \& McCabe, 2017; Lee \& Kotler, 2015; Prothero \& Fitchett, 2000). The discrepancy between everyday sustainability behaviours and those exhibited in decision-making practices in tourism (Barr, Shaw, Coles, \& Prillwitz, 2010; Cohen, Higham, \& Reis, 2013; Miller, Rathouse, Scarles, Holmes, \& Tribe, 2010) means that tourism specific research is needed to understand how sustainability marketing differs to marketing commodities or behaviour change in habitual situations. Although there seems to be a persistent lack of public engagement with sustainability in tourism, we know little from a marketing perspective as to why this is the case (see Weeden, 2014).

Sustainability marketing has traditionally focused on how to overtly market sustainable products, with a view to mobilising sustainable behaviour as a central, rather than peripheral, activity (McDonagh \& Prothero, 2014). This has led to communicating sustainability product features as if these are key purchasing attributes, a phenomenon labelled as green or sustainability marketing myopia because of its over reliance on altruistic consumer interest in sustainability (Ottman, Stafford, \& Hartman, 2006; Villarino \& Font, 2015). This approach has been problematised (Grant, 2007; Rex \& Baumann, 2007), suggesting that the route to mainstreaming sustainable production and consumption requires more than increasing the market share of deep green consumers, but instead requires making all experiences more sustainable. 
While the direct correlation between increased interest in sustainability in tourism and greater demand for tourism products that are embedded with sustainability principles has yet to be directly proven through research, there is however a noted emphasis on tourists searching for experience, and connection within authentic and ethical encounters (Weeden, 2008). A focus on how specific sustainability features help consumers fulfil their hedonistic travel desires requires a more pragmatic approach that links notions of sustainability to tourist experiences through the significant contribution that elements in sustainability can have on the facilitation of Memorable Tourism Experiences (MTE's) (Agapito, Valle, \& Mendes, 2014; Kim, 2014; Kim, Ritchie, \& McCormick, 2012; Pine \& Gilmore, 1999). Through the creation and portrayal of experience in sustainability marketing, factors concerned with the environment and local culture in destinations could act as unique selling points, providing benefits to consumers, without explicitly drawing on notions of sustainable tourism as being in opposition to 'mass tourism' (Caruana \& Crane, 2008), or providing a narrative centred on 'doing tourism differently' or 'saving the world' (Butcher, 2002).

It is our contention that there is a need for further in-depth investigations to explore the complexities of human engagement with discourses of sustainability in a tourism destination marketing context. This will help us to understand not only how destination promotional campaigns influence behaviour, but also provide insight into and hence overcome some of the barriers preventing positive change (Becken, 2007; Verbeek \& Mommaas, 2008). The objective of this article is to further understand the questions that arise regarding the ways in which consumer engagement and response to advertising and promotion is intrinsically connected to the successful marketing of sustainability for a tourism destination. This paper explores consumer interpretations of a marketing campaign conducted by a leading European 
destination. It contends that overt discourses of sustainability are often rejected by tourists, thus leading to the suggestion that marketing messages concerned with sustainability should place greater priority upon the opportunities afforded by purchasing and consuming a responsible travel experience. As such, commitments to sustainable destinations manifest within organisational philosophy and practice should not drive the principle, overt discourse communicated to consumers. Rather, as embedded within product and practice, such messages would have greater power and effect if they occupied a more subliminal position.

To offer some context for this, we firstly present an account of existing research in the area of sustainable tourist behaviour and the marketing of sustainability in tourism and destinations. The paper then moves on to explore the role of experience in consumer decision making. The methodology for this research is then presented followed by a presentation of our analysis. Finally the paper concludes with a discussion of the role of both sustainability and experience in the marketing of tourism destinations to offer the suggestion that more implicit marketing strategies are needed to move away from a reproduction of the distinction between 'mass' and 'sustainable' tourism, towards one that collapses this arbitrary distinction and facilitates all forms of tourism to be underpinned by notions of sustainability.

\section{Tourist decision-making, sustainability and marketing}

First, our attention turns to the conceptualisation of consumer behaviour in the context of sustainable tourism and the emergence of ethical consumption in tourism. Tourist decisionmaking has long been the focus of both researchers and practitioners (Sharifpour, Walters, Ritchie, \& Winter, 2014), and its inherent complexity means it remains a subject of intensive 
study. Recognition of the importance of experience, and factors such as emotion (Moons \& De Pelsmacker, 2012), self-identity (Varul, 2009), a sense of responsibility (Wells, Ponting, \& Peattie, 2011), and motivational complexities in decision-making (Jägel, Keeling, Reppel, \& Gruber, 2012) have contributed to a rejection of the consumer as rational decision maker, as proclaimed in traditional decision-making models (see Engel, Kollatt, \& Blackwell, 1968; Howard \& Sheth, 1969; Nicosia, 1966). These assume consumers move in a linear way through problem identification, information search, evaluation of alternatives, choice and post-choice processes, an approach now considered inappropriate, especially when investigating a multifaceted and challenging area of study such as green/ ethical consumption (McEachern \& Carrigan, 2012). Marketing strategies with overt altruistic sustainability messages follow this traditional decision-making model mentality of providing factual sustainability information, whereas understanding tourists as complex emotional decision-makers will suggest we need to design hedonistic messages that appeal to tourists' desire for experiences (Villarino \& Font, 2015).

We argue that information exchange alone seems limited in attempting to change behaviour. While awareness of the global impacts of human consumption has become significantly more apparent around the world, little has been achieved to move towards a more sustainable society (Buckley, 2012). It is our understanding of the effects such knowledge and understanding have on tourists' purchasing choice that has recently come to the fore of research. For some, the effects of climate change are considered the driving force of a gradual general behavioural transformation (Scott, Gössling, \& Hall, 2012), supported by evidence of increased purchasing of sustainably labelled goods (CooperativeBank, 2010). Yet significantly, while UK consumers have higher than average awareness of ethical product choices, their 
consumption of sustainable products lags behind those of neighbouring European countries (Sudbury Riley, Kohlbacher, \& Hofmeister, 2012). This increased awareness of environmental impacts only makes more obvious the gap between the values, attitudes and intentions of consumers and their actual behaviour (McEachern \& Carrigan, 2012; Young, Hwang, McDonald, \& Oates, 2010), explained as a rejection of threats to ones' right to consumerism, in the context of not being able to travel (Font \& Hindley, 2016). Miller et al (2010) suggest that a clear distinction exists between environmental awareness, public understanding of sustainability within everyday purchasing behaviours, and that associated with travel and tourism related purchases. Essentially, consumers' heightened awareness and good intentions do not translate into greater levels of sustainable tourism consumption, with desire for responsible purchases traded off in the market place in favour of other, more appealing options (Devinney, Auger, \& Eckhardt, 2010). The challenge is therefore to design sustainable holidays to appeal to the hedonistic nature of travel (Malone, McCabe, \& Smith, 2014). This requires putting the consumer at the centre of the (sustainable) experience, which has not always been a key strength of tourist destinations (King, 2002; Serra, Font, \& Ivanova, 2016).

Too much emphasis on sustainability within promotional material can have a negative effect on tourists' purchase behaviour, leading to an increase in 'traveller's guilt,' and greater levels of discomfort, dissonance, denial, a delegation of responsibility to other actors, and increased demand on the unsustainable product (Becken, 2007; Font \& Hindley, 2016; Scott et al., 2012). This perception of sustainable tourism activities and holidays being in some way less appealing, and requiring sacrificial behaviour, may be key to understanding barriers to sustainable holiday purchasing. For instance, Caruana et al. (2014) undertook research into the personal accounts of tourists on a 'responsible travel' experience in order to gain insight 
into their motivations, and identify what, if anything, differentiated these individuals from 'regular' tourists. Their study revealed tourists who expressed higher levels of involvement and intrinsic motivations in responsible tourism were also driven to seek pleasure and relaxation, similar to the research by Malone et al. (2014). Likewise, Weeden (2011) reported responsible tourists believed they deserved to fly because they prioritised sustainable behaviours in their everyday lives. Yet, within the context of travel and tourism, such negotiations remain relatively unexplored. Indeed, while these issues are evident in studies seeking to clarify ethical consumer decision-making (Carrington, Neville, \& Whitwell, 2014), the specific nature of the role of marketing in the anticipatory construction of the tourist experience, and the importance, and habitual nature of leisure travel to consumer lifestyles, have so far been neglected. It is to an analysis of existing work on sustainable marketing that attention now turns.

\section{Marketing sustainability in destinations}

The economic value of the global tourism industry has created an increasingly competitive market, with marketing integral to the success of a destination seeking to secure commercial advantage (Pike \& Page, 2014). Destinations are a complex amalgam of tourist products and services (Buhalis, 2000), and are thus required to balance a varied set of attributes, stakeholders, and actors in the co-creation of tourist experiences, whilst simultaneously engaging with the sustainability agenda (Fyall, Garrod, \& Wang, 2012). As a key element within a package of differentiated appeal, it has been claimed that the marketing of sustainable attributes can enhance destination competitiveness (Fjelstul, 2014). The effective marketing of sustainability in destinations may potentially reduce the perceived burden of 
responsibility on the consumer, and act as a key factor in the consumer decision-making process, as long as other aspects such as price and quality are comparable (Goodwin, 2005).

Dolnicar and Leisch (2008) suggest the selective targeting of environmentally conscious travellers could aid destinations that seek to sustain their natural and social environments through the attraction of tourists with smaller environmental footprints. In support of this, research has identified a range of distinct market segments that could be described as environmentally friendly, incorporating various characteristics desirable to destination managers (e.g. Dolnicar, 2004). This approach to marketing sustainability features stems from a perception that it is the responsibility of marketers to educate visitors on how they can reduce their negative impacts on a destination (Pennington-Gray, Reisinger, Kim, \& Thapa, 2005). Selectively marketing destinations to environmentally friendly tourists may seem like a logical plan to attract sustainable-oriented tourists, however this technique disregards a large section of tourists at any one destination and as such, can have only limited success in mobilising significant behaviour change within the industry. The idea of simply targeting a favourable segment is at best, economically unsustainable and at worst, negatively enhances the unsustainability of other, non-environmentally focused forms of tourism. Indeed, it is contradictory to the principles of sustainability in which all forms of tourism and their operations have the potential to become more sustainable.

We argue the priority is to maximise the number of consumers purchasing more sustainable products, knowingly or not. There is evidence that tourists provided with information about sustainability before and during a trip have a more enjoyable experience. Similarly, studies argue that learning is a considerable influence on memorable experiences and motivations 
(Kim et al., 2012; Tung \& Ritchie, 2011). Hence the call to place the customer at the centre of the destination experience, to which we turn next.

\section{Sustainability, marketing and the experience economy}

The experience economy (Pine \& Gilmore, 1999) is a critical element in modern consumerism, arising out of greater wealth and freedom, and an overarching need to develop ones individual identity and gain personal experiences in accordance with lifestyle choices, values and beliefs. These experiences become a part of the person and how they see themselves, and infers they carry the potential to create pleasure and satisfaction above what could be obtained through the consumption of products and services alone (Mehmetoglu \& Engen, 2011). For this reason, the development and enactment of unique and memorable experiences can add significant value for both consumer and producer, which thus offers opportunity for destination differentiation and advantage (Mei, 2014). It is fair to say that destination marketing organisations are struggling to adapt to this change in approach (Lugosi \& Walls, 2013; Morgan, Elbe, \& de Esteban Curiel, 2009).

Tourists increasingly demand a wide range of experiences as they come to know and understand destinations (e.g. Bæderholdt, Haldrup, Larsen, \& Urry, 2004; Franklin \& Crang, 2001; Scarles, 2009; Urry \& Larsen, 2011). Visitor satisfaction is therefore dependent upon the extent to which a destination delivers tourists' aspirations for authentic experiences (Morgan et al., 2009). Kim et al. (2012) identified 24 components of tourist experiences categorised into seven overarching domains. These domains attempt to incorporate the different experiences on offer at most tourism destinations that are likely to affect ones memory; Involvement, Hedonism, Refreshment, Local culture, Meaningfulness, Knowledge 
and Novelty. Many of these components have the potential to connect with tourists' emotions causing increased attention span, learning ability and happiness, ultimately leading to memory retention (Larsen \& Jenssen, 2004; Tung \& Ritchie, 2011). We argue that mainstreaming sustainability value through communication starts with a focus on methods to promote, deliver and recall experiences via these domains.

The focus on evoking emotions is an important factor in the creation of a memorable experience and is often associated with our senses and the significance of sensual experiences. According to Agapito et al. (2014) the most sensual tourism experiences rely predominantly on nature from beach-based holidays to rural retreats with the heightening of multiple senses simultaneously. It was found that tasting local food and the smell of fresh air were two of the most important sensual experiences to tourists suggesting that the aims and elements of sustainable tourism development go hand in hand with the creation of meaningful and memorable sensual experiences (Agapito et al., 2014). Such transformational experiences are what all experience-based services should be looking to provide, tourism being arguably one of the best equipped industries to offer this (Pine \& Gilmore, 2014). A destination with sustainability features can therefore be best placed to deliver such experiences, although the marketing message needs to be hedonic, that is, customer centred (Malone et al., 2014).

By advocating a shift to a more subliminal, covert approach to communicating commitments to sustainable tourism, and focusing attention on the experiences realised through such products, it is vital to reflect upon the practices adopted by destinations to achieve such knowledge dissemination amongst tourists as prospective consumers. It is much more 
persuasive to promote experiences in a setting that is sustainably managed, than to visually present sustainability per se (Wehrli et al., 2014). As tour operators 'stage' destinations using visuals as objects upon which tourists imaginatively perform; guiding and regulating to reinforce and encode hegemonic meanings and understandings of place (e.g. Scarles, 2009), interest lies in the effectiveness of both overt and covert narratives and discourses of sustainability within the construction of the visuals utilised within marketing and promotion campaigns.

Thus, practices of sustainability are inherently interwoven with practices of marketing, as destination management organisations use visuals to convey the experiences that await tourists, whilst simultaneously and either overtly or covertly educating and informing tourists about the practices, habits and behaviours that are deemed appropriate for the shared experiences in the destination (Scarles, 2009). Attention now turns to exploring the effect of overt and covert communication of discourses of sustainability on tourist understanding of destinations and their touristic experiences in relation to a sustainable tourism destination marketing campaign.

\section{Methodology}

This research aimed to gain insight into human behaviour and influences resulting in the creation of a core contribution to existing theory and practice in the field. This research draws on focus group data with UK based potential tourists to explore the socially negotiated understanding (e.g. Bryman, 2004) of destinations, issues of sustainability in tourism, and specific destination marketing material with either a focus on pleasure and experience, or a focus on sustainability. This allows for an in-depth exploration of the views, values, opinions 
and perceptions of participants and the ability to probe deeper if required to allow for potential uncertainties (Nykiel, 2007). The use of focus groups also allows for participants to interact and discuss thoughts and ideas, potentially giving rise to a wider range of responses on experiences.

This research utilised a non-probability, purposive sampling method, which allowed for the researcher to select participants appropriate to the purpose of the study. To achieve this, a social network sampling technique was adopted where the researcher selects participants from within their social network and snowballs out from this cohort (Bryman, 2004). This technique can however, increase clarity and comfort within the group as participants can be sure that each person is known by the researcher in some way. Whilst the country destination cannot be explicitly named in this research, it should be noted that it features in the top five of the most visited European destinations (UNWTO, 2016), and is well ranked in sustainable cities (Batten, 2016).

The focus group topic guide was split into three sections: destination knowledge and experiences; general perceptions of sustainability and tourism; and responses to two marketing campaigns. The two marketing campaigns were concerned with the same destination but utilised sustainability in different ways. Campaign one included images of the destination (images) and a tourism marketing video (video 1), neither the images nor the video placed any emphasis on the environmental credentials of the destination or on sustainability more generally. Campaign two however incorporated an entirely different strategy with the use of a brochure (brochure) and a video (video 2). To incorporate elements 
of sustainability in to both the brochure and video 2 audio and visual messages emphasised the environmental credentials of the destination, these were also often accompanied by textual information explicitly informing the viewer of, for example, the sustainable transport network at the destination. These campaigns were assessed against the criteria of sustainability marketing myopia developed by Villarino and Font (2015). The standard marketing campaigns were deemed to set aspirational holidays in a setting with sustainability potential, and encouraged activities that could have been labelled as sustainable, but were not explicitly sold as such. Instead, the two explicit sustainability marketing campaigns used pro-environmental language, and emphasised the benefit to the destination in more instances than the consumer benefit.

Four focus groups took place, with 5 to 7 participants' resident within the UK in each. In total, 26 individuals took part of which 12 had previously travelled to the destination. Group 1 had only experienced travellers, groups 2 and 3 were mixed, and group 4 had no previous travel experience of the destination. All participants were between 18 and 35 years old, except Sandra and Sally, who were in their 60s and had no experience of this destination. Anonymity and informed consent were guaranteed for the participants and pseudonyms have been used, and the decision to keep the destination anonymous was taken to emphasize the generisability of the findings. Each focus group lasted between 45-90 minutes.

INSERT TABLE 1 HERE 
Following the completion of each focus group, the recordings were transcribed verbatim, and thematic analysis was adopted to identify, analyse and report patterns within the data (Braun \& Clarke, 2006). This process is ideal for socially negotiated focus groups where similarities and differences between accounts form key components following which representative themes are developed. Two members of the research team analysed the data by reading through, making notes and developing themes with the question of 'how do individuals receive and understand marketing campaigns with explicit vs implicit sustainability content?'. To further develop the analysis, the researchers examined the data with specific areas in mind that had emerged out of the literature review. These areas included: understandings of sustainability; experiences and expectations of the holiday; relationships between sustainability and the tourist experience; responses to direct and indirect marketing messages from this destination.

\section{Findings}

In line with previous research by authors such as Miller et al (2010), findings suggest that group participants' awareness and understanding of sustainability was largely centred on environmental concerns, with limited understanding of social concerns despite the central role of such issues within the overall agenda of sustainable tourism. For example, as Ronda from Focus Group (FG) 1 highlights:

I think people just think sustainability is about the environment, but it's also about the communities and the people that live there and it's making sure that you'd behave how you'd want other people to behave when they visited where you live, I think it 
incorporates a lot of different aspects not just 'oh we have to look after the environment', there's a lot of other things as well

However, unlike findings by Miller et al (2010) where respondents had difficulty in articulating the impacts of tourist activities, many participants were able to identify examples of past experiences or general knowledge to illustrate their points; both Leon in FG3 and Tim in FG1 mentioned the Great Barrier Reef as an example of the negative impacts of tourism. Other examples included tourist destinations in Spain with Sally in FG3 and Sindy in FG2 both suggesting that tourism has had a negative impact resulting from over development and a lack of regulations and control. For example, as Sally (FG3) comments "I went to Spain in late June and I've never seen so many thousands on a beach. I could not imagine that you could have so many thousand people on a beach. Because what they did is just, they built the hotels in the first line of the coast so the people just go to the beach". There was also a clear appreciation among participants of the negative environmental impacts of flying. David in FG1 saw aircraft as a big challenge for sustainability, noting that "aircraft are a big challenge...everyone is flying everywhere", while Jack (FG3) suggested that by flying people are having significant impacts on global environments.

However, despite previous work by Barr et al. (2010), Cohen, Higham, and Cavaliere (2011), and Hares, Dickinson, and Wilkes (2010), that suggests a relative ambivalence towards issues surrounding sustainability, such concerns were voiced as being extremely important by participants across all focus groups. For example, Sally (FG3) comments "If I thought by going somewhere I was adding negative things to it that might make me think well perhaps I won't 
go there, I'll go somewhere where I'll make a less negative impact". There was also a significant importance placed upon the preservation of attractions for future generations to enjoy; a point exemplified by Ronda's (FG1) reflection that "it's doing what you can to live but making sure you preserve it for future generations as well, rather than just like having this attitude that we live in the now and that we're not going to preserve things for the future". Such a position shows a clear understanding of the basic concept of sustainability. What is interesting for the purpose of this study is the ways in which participants respond to the position of discourses of sustainability in the marketing and promotional material of the selected destination elicited to them in the course of the focus groups, discussed next.

\section{The limited persuasiveness of overt messages of sustainability}

The data presented in this section exemplifies well the attitude-behaviour gap of sustainable tourism (Juvan \& Dolnicar, 2014). Findings suggest that all participants would welcome additional information relating to sustainability, as many, like Lilly (FG2), Jasper (FG2), and Mary (FG4), suggested that people need to be taught how to travel responsibly. As Lilly (FG2) noted: "it's not only about the place itself being sustainable, it's also about teaching people how to travel properly". Likewise, Leon in (FG3) stated that the provision of information is key in allowing consumers to make decisions and therefore increase sustainable behaviour. As he comments "I think that if that information is available then that really is the point, if the information is available then you can make an informed decision, I think the majority of people, if there's not too much cost differential, would go for the one that's economically and ecological sustainable". In his account, the provision of information on sustainability was thought to increase sustainable behaviour by acting as a tie-breaker, as suggested by 
(Goodwin, 2005). Sally in (FG3) stated that she would choose the sustainable option over another as it would likely make her feel better about the purchase, supporting the claim for traveller's guilt (Scott et al., 2012).

However, despite such unanimity, there was a range of responses as to the format that such information should take. Likewise, disparities quickly emerged when participants were asked about how their understanding and views of sustainability and tourism influence their travel decisions as it became clear that views or values rarely translate into actual behaviour (Devinney et al., 2010). Rather, in line with Pine and Gilmore (1999), participants prioritised the promise of meaningful experiences and encounters over commitment to sustainability at a destination. For example, in FG3 all participants agreed that sustainability does not feature in their travel considerations explaining that they travel for pleasure and any sustainable actions are a by-product of other primary considerations like the desire to stay with friends or relatives. As Jasper (FG2) comments, sustainability becomes an added-value benefit of the product purchased:

I think they need to sell the place before talking about sustainability because sustainability is an extra incentive, thinking 'wow it looks great AND it's this (sustainable) rather than 'it's sustainable!'

This view was supported by most participants who suggested that sustainability does not attract them to a destination although unsustainable destinations that impede on the tourist experience would act as a deterrent. For example, Ben (FG2) talks of his upbringing in rural Wales and how in everyday life he acts in an ethical manner through buying organic and voting 
green. It also highlights the disparities between sustainable purchasing behaviours in our dayto-day lives, and our behaviours when purchasing tourism (Barr et al., 2010; Miller et al., 2010). As such, the implicit nature of sustainability in destination development and experience creation comes to the fore, as he comments:

In terms of holidays though it's probably not something that I really, honestly is that something I think about in terms of holidays not so much I think perhaps you have sort of things that push you and things that pull you. Sustainability isn't something that pulls me towards a holiday destination but if I found out that somewhere was doing something that I didn't agree with morally, wasn't in line with my politics, my values then that might push me away from going there.

In the other focus groups there were similar reactions. Whilst there was a clear appreciation of information concerning sustainability, this content was often seen as overly emphasised resulting in the neglect of other information that may be of more interest. For example, as Scott (FG4) comments:

Good to know that they're doing all of that sustainably, that's a nice cherry on the top. I don't think I needed to know quite so much about how sustainable it is. It's sustainable, that's good, that's all I need to know.

Although focus group participants appreciated being given information on the destination's sustainability in both the brochure and video 2, many participants suggested that the sustainability focus was too present, potentially offering 'information overload' (Seyfang, 
2011), and that it may have resulted in the inadequacy of information regarding other important aspects of the tourism experience.

Thus, it appears that utilising sustainability and 'environment management' too explicitly results in a neglect of other more appealing attributes that facilitate MTE's like 'place attachment' and 'variety of activities' (Kim, 2014; Wehrli et al., 2014). Such an imbalance resulted in the marketing campaign missing the important element of attracting potential consumers through sustainability myopia (Villarino \& Font, 2015). A point highlighted by Leon (FG3):

It's interesting because I felt like a lot of the messages there was something that would really appeal to me like, the sustainability of it. That's stuff that definitely I want to know about, but at the same time I don't want to necessarily know every little detail about the place. I want to kind of know what can you offer me, whereas I feel like they're telling me so much about, kind of, all the intricacies of the area, I'm losing maybe a little bit of a sense of all the activities I could do.

From the above, it can therefore be suggested that there is a need for a more subtle understanding of sustainability to come through the marketing of sustainable tourism destinations which centralises the focus on the consumer as opposed to sustainability. Overt messages of sustainability appear to neglect what attracts the consumer, despite their desire for such information (e.g. Seyfang, 2011), and consumers reject engaging with products that are perceived to be too costly, not only in financial terms but also in increased risk, reduced 
pleasure, increased level of effort, amongst others (Diekmann \& Preisendörfer, 2003). As the following exchange (FG1) highlights:

Sabrina: They were trying to get people to go on like a greener holiday, erm, all of the sustainable things but in a more obvious way. This is what it is; this is what we do to make you want to do it

Tim: They made it a focus as opposed to a by-product.

Sabrina: It was more 'in your face'.

\section{The old and the new}

In addition to information on the destination's sustainability potentially resulting in an information overload, there was also a strong association between this and notions of modernity. For example, whilst nearly sixteen years have passed since Leist and Holland's (2000) influential critique of environmental preservation as attempting to freeze or ' $\mathrm{fix}$ ' nature in a way that is deemed 'natural', and Kuhn's (2007) assertion that sustainable tourism attempts to preserve cultures in a way that the western tourist sees as 'authentic', the participants in this research explicitly highlighted this problematic aesthetic assumption. For example, as the following exchange in FG2 highlights:

Lilly: There is kind of a controversy because sustainability is also related to modernity now, and you see that and it looks a bit old, like sustainable but old and it's just like when they speak about the electronic car, electric car, yeah that's good, that's really modern, that's great for the environment, seeing that in this kind of video I'm like, no, it doesn't fit the content they are showing, it's just too... 
Ben: I think for those kind of things to move me they have got to be part of something more emotional, like movements, things to do with emotions, change and perhaps more political somehow than that

In addition, not only was the explicit marketing seen as being old, but it also recalled notions of 'green washing' (e.g. Smith \& Font, 2014). The concept of sustainability was understood as being dated, unable to offer a unique selling point, yet something that has become the norm and an implicit expectation of potential tourists. As Ronda (FG1) comments:

I think the whole word 'sustainability' is old now, people are using different things, everybody has a sustainability policy, everybody has a sustainable holiday and obviously they are incorporating all these words but they are still calling it sustainability.

Whilst these broader associations of modernity and norms are certainly something that needs to be considered in the marketing of sustainable tourism destinations, there was also a complex association between age and the explicit marketing of sustainability through the different destination marketing campaigns presented to the participants. For example, in their response to video 2's explicitly sustainable marketing material, many participants felt the video was aimed at a much older age group. As the following exchange in FG2 highlights:

Binaca: I think it's made for an older audience. If my mum and dad watched it they would love it but for me, probably echoing what other people have said, it just doesn't really connect 
[and 5 minutes later]

Simon: It's going to appeal to certain types of people if you like that kind of....

Linda: 60 year olds! [laughs]

At this level, notions of sustainability appear to differ from these individuals' notion of their social identities (Tajfel, 1974) resulting in a situation whereby they are not only split from the 'other' group (e.g. 60 year olds), but more importantly are discouraged from a destination due to its undesirable trait associations (Aquino \& Reed II, 2002). A similar position was highlighted in relation to the political identity of sustainability and its undesirability, as lan (FG4) highlights "like the greens may talk about sustainability and some others may even make fun of them, like, they will say, you're a nerd, why are you talking about this stuff". Such are some of the associations with the explicit constructions of sustainability that it can completely put people off a destination, as Sabrina (FG1) rather aptly comments: "It makes me not want to go on that particular holiday".

Thus far we have explored the ways in which there appears to be a conflict between participants' stated need for information on sustainability and the shortcomings associated with information overload. In addition, we have highlighted the ways in which sustainability, modernity and social identities appear to offer further issues in terms of our participants' responses to an explicitly sustainable marketing campaign. The following section examines the ways in which hedonistic experiences continue to be prioritised over overtly altruistic concerns of sustainability. 


\section{A hedonistic experience}

One of the main ways in which sustainability was discussed was through the emphasis placed on bad experiences and negative impacts of unsustainable tourism in destinations. These seemed to have more of a significant direct influence on participants than any potential positive industry behaviour. For example, in FG3 Sally identified the negative implications of all-inclusive resorts with reduced visitor experience due to not leaving the resort stating "your experiences are less [...] because if you stay in that environment you are not really discovering". Bridget (FG3) highlighted a link to authenticity stating that tourists are offered staged experiences in popular tourist destinations that reduces overall enjoyment of the travel experience. As she notes "It's catering for the tourist isn't it, rather than you're going to actually experience... you're not actually experiencing... the authenticity of the place". This emphasises the role of sustainability not only in the creation of memorable experiences as suggested by Agapito et al. (2014) but also in the prevention of lasting negative memorable experiences (Kim, 2014).

Apparent in all four focus groups was a keen preference for the advertising strategies that emphasised the consumers' needs and destination experiences, as opposed to the print and video adverts highlighting the sustainability credentials of the destination. For example, when evaluating how they felt about the explicitly sustainable brochure, a number of participants suggested they would not travel primarily for sustainability and thus the brochure needed to include more information on the specific activities and attractions on offer as opposed to such aspects. As Stephen (FG1) comments: "If it was more split down into interest-based, what 
you're actually looking for, like, if you wanted to spend time out in the countryside or if you wanted to go cycling".

Thus in support of Caruana et al. (2014) it appears that in the marketing of a destination there is a need to emphasise elements of pleasure, excitement and relaxation in what a destination can offer potential tourists. There is sufficient evidence that even consumers that overly claim to be deep green actually prefer the hedonistic holiday messages in tourist brochures (Wehrli et al., 2014). Participants emphasised their desires to visit naturally beautiful destinations with interesting local cultures and heritage. This suggests that sustainability would enhance the attraction of natural surroundings in destinations, which ultimately enhance the tourist experience. As Leon in (FG3) comments:

It was interesting because I felt like a lot of the message there was something that would appeal to me like the sustainability of it and the fact that they've got rangers there, that's stuff that definitely I want to know about as a younger person booking. But at the same time, I don't want to necessarily know every little detail about the place, I what to kind of know what can they offer me, like, you know, how far are the hikes, like where can I go off and camp anywhere, and like can I go and do a rapids experience or something, you know. [...] I feel like they're telling me so much about all the little intricacies of the area I'm losing maybe a little bit of the sense of all the activities I could do

This offers an example of how participants expressed their desires and expectations where culture and history, the natural scenery, as well as unique experiences associated with the 
country, were expressed as primary travel considerations. Thus in support of Mei (2014) it appears competitive advantage is gained through a focus on experience as opposed to the presentation of explicit discourses of sustainability as the 'good' that an individual is 'doing' through their holiday.

Indeed, video 1 many commented on the diversity of the country, stating that the video had shown a variety of attractions and that there seemed to be "something for everyone". This positive attribute corresponds with research by Mehmetoglu and Engen (2011) who emphasise the importance of variety in the creation of memorable and meaningful experiences. Considering the importance placed on unique experiences within participants' primary considerations and research by Kim (2014) regarding practical destination attributes that help to facilitate MTE's, this could be a significant reason for the overall lack of appreciation for video 2 in comparison to the first.

With the exception of two older participants in FG3 (Sally and Sandra), everyone else expressed a clear preference for the marketing of a destination which placed consumer experience centre stage. Thus, throughout the responses to different marketing material presented to the focus groups it appears that sustainability alone does not act as a key positive factor in how our participants understood and responded to the marketing campaigns. Indeed it was often quite the opposite. Therefore it appears that emphasis needs to be placed on the specific activities and attractions of a destination, with sustainability embedded within the preservation and uniqueness of the destination. 


\section{Conclusion}

Throughout this article we have attempted to represent the ways in which potential UK tourists respond to the marketing of a destination through traditional marketing strategies (emphasising what the potential tourist can get from the destination) and explicitly sustainable marketing strategies (where sustainable credentials of the destination are placed as central). We highlighted the ways in which sustainability and responses to the explicit marketing of sustainability raised issues for the ways in which participants understood sustainability as a factor that positioned the destination in a past time and also was associated with undesirable social identities. The analysis highlighted the ways in which, for our participants at least, the main draw for them to a destination was their own hedonistic experience. We argue ]this is further evidence that a myopic approach to communicating sustainability is unlikely to be as persuasive as an experiential and hedonistic approach (Grant, 2007; Malone et al., 2014; Rex \& Baumann, 2007; Villarino \& Font, 2015).

Whilst this could be understood in the context of the selfish, individually driven consumer, we propose that it could be taken forward in a more positive light. By this, we suggest that with natural environments potentially offering a playground for the hedonistic experience, sustainability needs to be fully embedded in the destination management with the preservation of natural environments becoming the central factor to attracting potential consumers.

As such, we argue that given the continued discrepancies between attitudes and behaviours of tourists' engagement with sustainability initiatives and practices in everyday life and on holiday (Barr et al., 2010; Miller et al., 2010), discourses of sustainability should be more 
implicit within marketing and promotional activities. In line with research that prioritises experiences, we suggest that elevating the role of implicit information dissemination through indirect communication strategies (such as using images or videos), holds greater power of persuasion as fears of information overload (Whitmarsh, 2009), displacement of personal priorities and motivation (Hares et al., 2010) and hedonistic freedom or choice are dispelled. Rather, commitments to sustainability become implicit in destination development and supporting infrastructures as the experience that awaits tourists comes to the fore.

Despite the findings of this research offering some interesting areas to consider, the research is not without its limitations. For example, whilst a strength of the focus group methodology is to enable an account of 'socially shared understandings' (Bryman, 2004) this also offers a series of limitations in terms of focus groups being steered by particular individuals and also often inhibiting individual expressions of understandings. Here we also recognise the limitations and lack of representation of our sample in terms of age, gender and ethnicity, all three demographics are said to have an impact on the way people understand and consume sustainable products and thus need further exploration in this context.

Further, the methodology adopted focused on one European host country and their marketing campaigns. This is a distinct limitation as individuals will exhibit some preconceptions about the country tied to socially organised notions of national identity and national stereotypes (Billig, 1995). Therefore we suggest that more research is needed, including experimental research that explores participant responses to a series of marketing strategies which include the explicit marketing of sustainable credentials, the explicit 
marketing of nature as a resource for the hedonistic experience, and examines the ways in which age, and other identity components mediate responses.

In summary, as this paper has attempted to highlight, few tourists engage with sustainable tourism products for altruistic reasons, and fewer still act in a consistently 'sustainable' manner whilst on holiday. Therefore, whilst sustainable tourism marketing (both textual and visual) has the potential to shape the consumer's appreciation of the destination, existing practices are still some way off facilitating sustainable forms of tourism as the 'norm'. 


\section{References}

Agapito, D., Valle, P., \& Mendes, J. (2014). The sensory dimension of tourist experiences: Capturing meaningful sensory-informed themes in Southwest Portugal. Tourism Management, 42, 224237.

Aquino, K., \& Reed II, A. (2002). The self-importance of moral identity. Journal of personality and social psychology, 83(6), 1423.

Bæderholdt, J., Haldrup, M., Larsen, J., \& Urry, J. (2004). Performing Tourist Places. Aldershot: Ashgate.

Barr, S., Shaw, G., Coles, T., \& Prillwitz, J. (2010). 'A holiday is a holiday': practicing sustainability, home and away. Journal of Transport Geography, 18(3), 474-481.

Batten, J. (2016). Sustainable Cities Index 2016: putting people at the heart of city sustainability. Retrieved from https://www.arcadis.com/media/0/6/6/\%7B06687980-3179-47AD-89FDF6AFA76EBB73\%7DSustainable\%20Cities\%20Index\%202016\%20Global\%20Web.pdf

Becken, S. (2007). Tourists' perception of international air travel's impact on the global climate and potential climate change policies. Journal of Sustainable Tourism, 15(4), 351-368.

Belz, F. M., \& Peattie, K. (2012). Sustainability marketing: a global perspective (2nd ed.). Chichester: John Wiley and Sons.

Billig, M. (1995). Banal nationalism. London: Sage.

Braun, V., \& Clarke, V. (2006). Using thematic analysis in psychology. Qualitative Research in Psychology, 3(2), 77-101.

Bryman, A. (2004). Social Research Methods (2nd ed.). Oxford: Oxford University Press.

Buckley, R. (2012). Sustainable tourism: Research and reality. Annals of Tourism Research, 39(2), 528546.

Buhalis, D. (2000). Marketing the competitive destination of the future. Tourism Management, 21(1), 97-116.

Butcher, J. (2002). The moralisation of tourism. London: Routledge.

Carrington, M., Neville, B., \& Whitwell, G. (2014). Lost in translation: Exploring the ethical consumer intention-behavior gap. Journal of Business Research, 67(1), 2759-2767.

Caruana, R., \& Crane, A. (2008). Constructing Consumer Responsibility: Exploring the Role of Corporate Communications. Organization Studies, 29, 1495-1519.

Caruana, R., Glozer, S., Crane, A., \& McCabe, S. (2014). Tourists' accounts of responsible tourism. Annals of Tourism Research, 46, 115-129.

Cohen, S. A., Higham, J. E., \& Cavaliere, C. T. (2011). Binge flying: Behavioural addiction and climate change. Annals of Tourism Research, 38(3), 1070-1089.

Cohen, S. A., Higham, J. E., \& Reis, A. C. (2013). Sociological barriers to developing sustainable discretionary air travel behaviour. Journal of Sustainable Tourism, 21(7), 982-998.

CooperativeBank. (2010). Ethical Consumerism Report 2010: Ethical Shopping Through The Downturn. Retrieved from http://www.goodwithmoney.co.uk/assets/Uploads/Documents/EthicalConsumerism-Report2010.pdf?token=0c2c344933ff34535798496b643cea3519277d70|1323784157\#PDFP

Devinney, T. M., Auger, P., \& Eckhardt, G. (2010). The myth of the ethical consumer. Cambridge: Cambridge University Press.

Diekmann, A., \& Preisendörfer, P. (2003). Green and greenback the behavioral effects of environmental attitudes in low-cost and high-cost situations. Rationality and Society, 15(4), 441-472.

Dolnicar, S. (2004). Beyond "commonsense segmentation": A systematics of segmentation approaches in tourism. Journal of Travel Research, 42(3), 244-250.

Dolnicar, S., \& Leisch, F. (2008). An Investigation of Tourists' Patterns of Obligation to Protect the Environment. Journal of Travel Research, 46, 381-391.

Engel, J. F., Kollatt, D. J., \& Blackwell, R. D. (1968). Consumer behaviour. New York: Holt, Rinehart, and Winston. 
Fjelstul, J. (2014). Vehicle electrification: On the "green" road to destination sustainability. Journal of Destination Marketing \& Management, 3(3), 137-139.

Font, X., \& Hindley, A. (2016). Understanding tourists' reactance to the threat of a loss of freedom to travel due to climate change: a new alternative approach to encouraging nuanced behavioural change. Journal of Sustainable Tourism, 25(1), 26-42.

Font, X., \& McCabe, S. (2017). Sustainability and marketing in tourism: its contexts, paradoxes, approaches, challenges and potential. Journal of Sustainable Tourism, 25(7), 869-883.

Franklin, A., \& Crang, M. (2001). The trouble with tourism and travel theory. Tourist studies, 1(1), 522.

Fyall, A., Garrod, B., \& Wang, Y. (2012). Destination collaboration: A critical review of theoretical approaches to a multi-dimensional phenomenon. Journal of Destination Marketing \& Management, 1(1), 10-26.

Goodwin, H. (2005). Responsible Tourism and the Market. Paper presented at the International Centre for Responsible Tourism, Occasional Paper No. 4, University of Greenwich.

Grant, J. (2007). The green marketing manifesto. Chichester: Wiley.

Hares, A., Dickinson, J., \& Wilkes, K. (2010). Climate change and the air travel decisions of UK tourists. Journal of Transport Geography, 18(3), 466-473.

Howard, J. A., \& Sheth, J. N. (1969). The theory of buyer behaviour. New York: John Wiley.

Jägel, T., Keeling, K., Reppel, A., \& Gruber, T. (2012). Individual values and motivational complexities in ethical clothing consumption: A means-end approach. Journal of Marketing Management, 28(3-4), 373-396.

Juvan, E., \& Dolnicar, S. (2014). The attitude-behaviour gap in sustainable tourism. Annals of Tourism Research, 48, 76-95.

Kim, J. H. (2014). The antecedents of memorable tourism experiences: The development of a scale to measure the destination attributes associated with memorable experiences. Tourism Management, 44, 34-45.

Kim, J. H., Ritchie, B. J. R., \& McCormick, B. (2012). Development of a Scale to Measure Memorable Tourism Experiences. Journal of Travel Research, 51(1), 12-25.

King, J. (2002). Destination marketing organisations-Connecting the experience rather than promoting the place. Journal of vacation marketing, 8(2), 105-108.

Kuhn, L. (2007). Sustainable tourism as emergent discourse. World Futures, 63(3-4), 286-297.

Larsen, S., \& Jenssen, D. (2004). The School Trip: Travelling with, Not to or from. Scandinavian Journal of Tourism Research, 4, 43-57.

Lee, N. R., \& Kotler, P. (2015). Social marketing: changing behaviors for good (5th ed ed.). Thousand Oaks, CA: SAGE.

Leist, A., \& Holland, A. (2000). Conceptualising Sustainability - Policy Research Brief. Cambridge research for the environment, 1-20.

Lugosi, P., \& Walls, A. R. (2013). Researching destination experiences: Themes, perspectives and challenges. Journal of Destination Marketing and Management, 2(2), 51-58.

Malone, S., McCabe, S., \& Smith, A. P. (2014). The role of hedonism in ethical tourism. Annals of Tourism Research, 44, 241-254.

McDonagh, P., \& Prothero, A. (2014). Sustainability marketing research: Past, present and future. Journal of Marketing Management, 30(11-12), 1186-1219.

McEachern, M. G., \& Carrigan, M. (2012). Revisiting contemporary issues in green/ethical marketing: An introduction to the special issue. Journal of Marketing Management, 28(3-4), 189-194.

Mehmetoglu, M., \& Engen, M. (2011). Pine and Gilmore's concept of experience economy and its dimensions: An empirical examination in tourism. Journal of Quality Assurance in Hospitality \& Tourism, 12(4), 237-255.

Mei, X. Y. (2014). Boring and expensive: The challenge of developing experience-based tourism in the Inland region, Norway. Tourism Management Perspectives, 12, 71-80.

Miller, G., Rathouse, K., Scarles, C., Holmes, K., \& Tribe, J. (2010). Public understanding of sustainable tourism. Annals of Tourism Research, 37(3), 627-645. 
Moons, I., \& De Pelsmacker, P. (2012). Emotions as determinants of electric car usage intention. Journal of Marketing Management, 28(3-4), 195-237.

Morgan, M., Elbe, J., \& de Esteban Curiel, J. (2009). Has the experience economy arrived? The views of destination managers in three visitor-dependent areas. International Journal of Tourism Research, 11(2), 201-216.

Nicosia, F. M. (1966). Consumer decision process: Marketing and advertising implications. Englewood Cliffs: Prentice Hall.

Nykiel, R. A. (2007). Handbook of marketing research methodologies for hospitality and tourism. London: Routledge.

Ottman, J. A., Stafford, E. R., \& Hartman, C. L. (2006). Avoiding green marketing myopia: Ways to improve consumer appeal for environmentally preferable products. Environment: science and policy for sustainable development, 48(5), 22-36.

Pennington-Gray, L., Reisinger, Y., Kim, J. E., \& Thapa, B. (2005). Do US tour operators' brochures educate the tourist on culturally responsible behaviours? A case study for Kenya. Journal of Vacation Marketing, 11(3), 265-284.

Pike, S., \& Page, S. J. (2014). Destination Marketing Organizations and destination marketing: A narrative analysis of the literature. Tourism Management, 41, 202-227.

Pine, J. B., \& Gilmore, J. (2014). A leader's guide to innovation in the experience economy. Strategy \& Leadership, 42(1), 24-29.

Pine, J. B., \& Gilmore, J. H. (1999). The experience economy: work is theatre \& every business a stage. Boston: Harvard Business Press.

Prothero, A., \& Fitchett, J. A. (2000). Greening capitalism: Opportuntities for a green commodity. Journal of Macromarketing, 20(1), 46-55.

Rex, E., \& Baumann, H. (2007). Beyond ecolabels: what green marketing can learn from conventional marketing. Journal of Cleaner Production, 15(6), 567-576.

Scarles, C. (2009). Becoming tourist: Renegotiating the visual in the tourist experience. Environment and Planning D-Society \& Space, 27(3), 465-488.

Scott, D., Gössling, S., \& Hall, M. (2012). Tourism and climate change: Impacts, adaptation and mitigation. Abingdon: Routledge.

Serra, J., Font, X., \& Ivanova, M. (2016). Creating shared value in destination management organisations: The case of Turisme de Barcelona. Journal of Destination Marketing \& Management.

Seyfang, G. (2011). The new economics of sustainable consumption: Seeds of change. Basingstoke: Palgrave Macmillan.

Sharifpour, M., Walters, G., Ritchie, B. W., \& Winter, C. (2014). Investigating the role of prior knowledge in tourist decsision-making: A structural equation model of risk perceptions and information search. Journal of Travel Research, 53(3), 307-322.

Smith, V. L., \& Font, X. (2014). Volunteer tourism, greenwashing and understanding responsible marketing using market signalling theory. Journal of Sustainable Tourism, 22(6), 942-963.

Sudbury Riley, L., Kohlbacher, F., \& Hofmeister, A. (2012). A cross-cultural analysis of proenvironmental consumer behaviour among seniors. Journal of Marketing Management, 28(34), 290-312.

Tajfel, H. (1974). Social identity and intergroup behaviour. Social Science Information/sur les sciences sociales, 13(2), 65-93.

Tung, V., \& Ritchie, B. (2011). Exploring the Essence of Memorable Tourism Experiences. Annals of Tourism Research, 38(4), 1367-1386.

UNWTO. (2016). Tourism Highlights 2016 Edition. Retrieved from http://www.eunwto.org/doi/pdf/10.18111/9789284418145

Urry, J., \& Larsen, J. (2011). The tourist gaze 3.0. London: Sage.

Varul, M. (2009). Ethical selving in cultural contexts: fairtrade consumption as an everyday ethical practice in the UK and Germany. International Journal of Consumer Studies, 33, 183-189. 
Verbeek, D., \& Mommaas, H. (2008). Transitions to sustainable marketing mobility: The social practices approach. Journal of Sustainable Tourism, 16(6), 629-644.

Villarino, J., \& Font, X. (2015). Sustainability marketing myopia: the lack of persuasiveness in sustainability communication Journal of Vacation Marketing, 21(4), 326-335.

Weeden, C. (2008). The values of ethical and responsible tourists. Unpublished PhD thesis. University of Glasgow.

Weeden, C. (2011). Responsible tourist motivation: how valuable is the Schwartz value survey? Journal of Ecotourism, 10(3), 214-234.

Weeden, C. (2014). Marketing responsible tourism. In C. Weeeden \& K. Boluk (Eds.), Managing ethical consumption in tourism (pp. 225-239). London: Routledge.

Wehrli, R., Priskin, J., Demarmels, S., Schaffner, D., Schwarz, J., Truniger, F., \& Stettler, J. (2014). How to communicate sustainable tourism products to customers: results from a choice experiment. Current Issues in Tourism, DOI:10.1080/13683500.2014.987732.

Wells, V. K., Ponting, C. A., \& Peattie, K. (2011). Behaviour and climate change: Consumer perceptions of responsibility. Journal of Marketing Management, 27(7-8), 808-833.

Whitmarsh, L. (2009). Social and psychological drivers of energy consumption behaviour and energy transitions. In S. Dietz, J. Michie, \& C. Oughton (Eds.), Political Economy of the Environment: An Interdisciplinary Approach (pp. 213-228). Abingdon: Taylor \& Francis.

Young, W., Hwang, K., McDonald, S., \& Oates, C. J. (2010). Sustainable consumption: green consumer behaviour when purchasing products. Sustainable Development, 18(1), 20-31. 